\title{
Modeling of CPM/LOB integrated Scheduling Technique for Repetitive Construction Projects: Case of Multiple-Crews with Fuzzy Time Data
}

\author{
Mai W. El-Nawawy ${ }^{1}$, Emad E. Etman ${ }^{2}$, and Haytham M. Sanad ${ }^{3}$ \\ ${ }^{1}$ Civil Engineer, Faculty of Engineering, Tanta University, Egypt \\ ${ }^{2}$ Concrete Structures, Structural Eng. Dept., Faculty of Engineering, Tanta University, Egypt \\ ${ }^{3}$ Structural Eng. Dept., Faculty of Engineering, Tanta University, Tanta, Egypt \\ Corresponding author e-mail: mai.wagih1993@gmail.com
}

\begin{abstract}
Project scheduling provides a good insight for the manager to complete the project on time. Project scheduling gives complete timing analysis of activities involved and identifies the critical ones. Critical Path Method (CPM) is the most widely used in planning and scheduling method for traditional (non-repetitive) projects to determine the critical path which determines the minimum completion time of a project.

Some construction projects consist of several similar or identical units, which are called repetitive projects. LOB technique has some drawbacks such inability to generate a clear critical path of the project schedule and calculating the total float because it is a graphical technique. LOB used for scheduling repetitive typical projects because this technique considered work continuity and resource availability constraints to avoid unnecessary crew idle time.
\end{abstract}

Some of the previous studies have been made to combine the benefits of CPM and LOB techniques in planning and scheduling repetitive construction projects, so, there is a model that was developed for this objective (schedule repetitive projects in an easy non-graphical manner). But, in real life, more conditions contributed to varying activity duration. Thus, the duration of project activities contains some sort of uncertainty affecting the estimating of project duration. Previous studies used fuzzy set theory instead of probability theory for quantifying the uncertainty associated with the duration of project activities.

In this paper, a developed integrated model of CPM and LOB with fuzzy time data for scheduling repetitive projects is presented. The developed model provides a new technique to schedule repetitive projects with fuzzy time data in an easy non-graphical manner.

Keywords: Construction projects, Repetitive projects, CPM, LOB, Uncertainty, Fuzzy sets.

\section{INTRODUCTION}

Project managers are under pressure to deliver the project on time and cost. On-time delivery requires an effective and realistic schedule appropriate to the nature of the project.

Many construction projects contain several identical or similar units, such as floors in multistory buildings, houses in housing developments, sections of pipelines, or highways.
According to Pioter Jaskowski (2015), repetitive construction projects are projects with activities that are repeated in similar or identical units. Construction projects that involve repetitive activities are usually designated as repetitive or linear projects such as multiple houses and typical floors in a high-rise building (repetitive projects) or highways and pipelines (linear projects). Scheduling techniques applicable to construction projects can be classified into two categories.

* Duration-Driven Techniques.

* Resource-Driven Techniques.

In duration-driven techniques such as CPM, activity durations are assumed functions of the resources required (rather than available) to complete each activity. The CPM formulation, therefore, assumes that resources are in abundance and cannot be used to determine what resources are needed in order to meet known project deadline duration. .In contrast, a resource-driven technique such as LOB is focusing on resources so that a project deadline is met using predefined resource availability limits. Its objective is to schedule the activities (determine their start and finish times) so that a project deadline is met using predefined resource availability limits.

Despite the wide application of CPM in construction management (Jaafari 1984), it fails on a practical basis to schedule repetitive projects (Fan and Tserng 2006).

The primary advantage of the LOB technique is maintaining work continuity of resources over the construction units (Mahdi 2004) then it is suitable for scheduling of repetitive projects. Efforts have been attempted to combine the benefits of CPM and Lob techniques. Integrated CPM and LOB model has been proposed to schedule non-serial repetitive activities in an easy, non-graphical manner similar to CPM analysis (Ammar 2013). Repetitive projects are normally executed in an environment characterized by varying degrees of uncertainties. The presence of these uncertainties in the scheduling process has a significant impact on estimating the duration of project activities then the total project duration. In this paper, an integrated CPM and LOB model with Fuzzy has been developed to combine the benefits of both models considering the uncertainties which are affecting the project activities and duration. The model consists of five steps, in which CPM calculations with fuzzy (F-CPM) are performed, LOB calculations with fuzzy (F-LOB) are performed, activity duration along all units is calculated, logical 
relationships and an associated lag between consecutive activities are specified, and integrated time analysis is performed. This paper is organized into five main areas:1) Literature of review 2) integrated CPM and LOB with fuzzy modeling 3) model automation 4) case study and 5) conclusion and future recommendation.

\section{Literature Review}

In construction projects, the main purpose of project management is to deliver a project on time within a given budget and satisfying quality. The development of a project Schedule serves several purposes before, during, and after the construction stage. Scheduling provides the project manager with critical and important information needed for executing the project in an efficient manner (e.g. activity times, activity floats critical activities, etc.).Although the Critical Path Method (CPM) is widely used in planning and scheduling for most projects, it is not suitable for scheduling repetitive projects because it does not consider work continuity. Repetitive projects represent a large portion of the construction industry. These projects face some challenges such as variable work quantities, work continuity, and resource constraints so, efficient planning and scheduling of projects are crucial. Thus, CPM- based techniques have been criticized widely in the literature for their inability to model repetitive projects because of it focuses on project duration and does not have the ability to provide work continuity for crews or resources (Selinger 1980; Russel and Wong 1993).In contrast to traditional CPM, the primary advantage of the LOB technique is maintaining work continuity of resources over the construction units (Mahdi 2004). LOB technique has been used to schedule repetitive activities such that a project deadline is met, such as those developed by Strdal and Cacha (1982), Suhail and Neale (1994), El-Rayes, and Moselhi (1998), and Lucko (2008). According to Hegazy et al. (2004), the objective of the LOB technique is to determine a balanced mix of resources and to synchronize their work so that they are fully employed and non-interrupted. Duffy et al. (2011) developed a model, termed linear scheduling model with variable production rates (LSMVPR).

Suhail and Neale (1994) developed a methodology to combine the benefits of CPM and LOB techniques into one model. This model is a good framework for CPM/LOB integration that determines the proper number of crews needed to meet a given deadline (Hegazy and Wassef 2001). The development of an integrated CPM/LOB model for scheduling and cost optimization of non-serial repetitive projects has been presented by Hegazy and Wassef (2001).

Ammar (2013) also presented an integrated CPM and LOB model that has been developed to schedule repetitive projects in an easy non-graphical manner, considering both logic dependency and resource continuity constraints.

Repetitive projects such as multistory buildings, highways, or pipelines are executed in an environment characterized by varying degrees of uncertainties. In the previous studies, two techniques were used to deal with uncertainties inherent in repetitive projects based on probability theory: Program Evaluation and Review
Technique (PERT) and Monte Carlo Simulation (MCS). In these techniques, the duration of an activity is estimated as a probability density function. To provide appropriate distribution for activity duration, historical data is usually needed. Previous studies have successfully demonstrated the use of fuzzy set theory for estimating the activities' durations. Maravas and Pantouvakis (2011) developed a fuzzy repetitive scheduling method (F-RSM) for managing and visualizing uncertainty in repetitive scheduling.

According to Abd-El-Khhalek (2014), a modified model for fuzzy network scheduling was developed to calculate the criticality degree of project activities and paths. Crew performance is influenced not only by the environment in which construction activities occur but also by crew motivation, which has largely been overlooked in construction research. However, construction researchers have faced challenges in identifying the effect of motivational factors and situational/contextual factors on crew performance. These difficulties are due to the uniqueness and dynamism of the construction environment and the fact that motivational and situational/contextual factors include both random and subjective uncertainties. To overcome these difficulties, two methodological approaches, agent-based modeling (ABM), and fuzzy logic have been applied and integrated to develop a model of construction crew motivation and performance (Raoufi and Fayek 2018b).

According to Raoufi and Fayek (2020), made three contributions: first, it expands ABM's scope of applicability by showing how to model both random and subjective uncertainty in ABM; second, it provides a novel methodology for integrating fuzzy logic and Monte Carlo simulation in ABM, which allows for the development of fuzzy Monte Carlo agent-based models in construction; and third, it illustrates a fuzzy Monte Carlo agent-based simulation of construction crew performance, which improves the assessment of crew performance by considering both random and subjective uncertainties in model variables.

\section{Integrated CPM and LOB with fuzzy Modeling}

An integrated CPM and LOB model with fuzzy time is developed to combine the benefits of both methods. In developing the proposed model, shortcomings of both CPM and LOB in planning and scheduling of repetitive projects are enhanced. A non-deterministic technique for scheduling repetitive projects called CPM and LOB Integrated Method for Scheduling Fuzzy Repetitive projects (F.CPM.LOB) will be presented in this paper. The proposed model essentially consists of five steps with an illustrative example is introduced to apply the developed model.

\section{Step1: F-CPM Calculations}

The objective of network scheduling calculations is to calculate the early start and finish times, the late start and finish times, and activity total float to utilize them in LOB calculations. CPM calculations comprise three types of 
calculations: forward path, backward path, and determining activities total float.

\section{A. Fuzzy Forward Path Calculations}

The steps involved in the Forward path calculations are similar to those performed in the critical path method (CPM). Forward pass calculations should be performed through fuzzy operations in an activity network of which the activity durations and lag/lead times are represented by fuzzy sets. For this reason, fuzzy addition, fuzzy subtraction, fuzzy maximization, and fuzzy minimization have been utilized to develop the procedure of the CPM forward pass calculation with fuzzy sets. The following equations are used to compute CPM with fuzzy early times.

$$
F E S_{x}=\max _{p \epsilon P}\left(F E F_{P}\right)
$$

where FESx is fuzzy early start of activity $x ; p$ is a predecessor of activity $\mathrm{x}$; and $\mathrm{P}$ is the set of predecessors to activity $\mathrm{x}$.

However, the construction project activity networks may include lag or lead times, and other dependencies such as SS and FF between activities. This problem is resolved by Subtracting fuzzy lead time from fuzzy lag time with fuzzy subtraction for each activity pair having a predecessor/successor relation as following by Eq.(2).

$$
F N_{p i}=\left\{\text { Fuzzy } \operatorname{Lag}_{p i}-\text { Fuzzy Lead } \text { Le }_{p}\right\}
$$

where $\mathrm{FN}$ is the fuzzy number and pi is the predecessor activity so that $i$ take values depending on the number of predecess-ors.

Add the fuzzy number calculated with fuzzy addition to the corresponding early time of the predecessor activity. If the dependency is SS, SF, FF or FS, the fuzzy early times are calculated as follows:

$$
\begin{aligned}
& \text { If relation is SS: } F E S_{s i}=F E S_{p i}+F N_{p i} \\
& \text { If relation is SF: } F E F_{s i}=F E S_{p i}+F N_{p i} \\
& \text { If relation is FF: } F E F_{s i}=F E F_{p i}+F N_{p i} \\
& \text { If relation is FS: } F E S_{s i}=F E F_{p i}+F N_{p i} \\
& \text { Then, } F E F_{x}=F E S_{x}+F d_{x}
\end{aligned}
$$

where $\mathrm{FEF}_{\mathbf{x}}$ is fuzzy early finish of activity $\mathrm{x}$; and $\mathrm{Fd}_{\mathbf{x}}$ is the fuzzy duration of activity $\mathrm{x}$.

Project duration is calculated from ending activities (ending activity is the activity that has no successors) as follows:

$$
T_{p r o j}=\max _{n \in N}\left(F E F_{n}\right)
$$

where $\mathrm{T}_{\text {projis }}$ the project completion time; $\mathrm{n}$ is an ending activity; and $\mathrm{N}$ is the set of ending activities.

\section{B. Fuzzy Backward Path Calculations}

Backward path calculations can being by first assigning project duration as a preliminary late finish for ending activities. This number is then used as a basis for determination of fuzzy late times of activities. The following equations are used to compute fuzzy late times.

$$
F L F_{x}=\min _{s \epsilon S}\left(F L S_{s}\right)
$$

where $\mathrm{FLF}_{\mathrm{x}}$ is fuzzy late finish of activity $\mathrm{x}$; $\mathrm{s}$ is a successor of activity $\mathrm{x}$; and $\mathrm{S}$ is the set of successors to activity $\mathrm{x}$.

However, the construction project activity networks may include lag or lead times, and other dependencies such as SS and FF between activities. This problem is resolved by Subtracting lag time from lead time with fuzzy subtraction for each activity pair having a predecessor/successor relation as following by Eq. (10).

$$
F N_{s i}=\left\{\text { Fuzzy Lead }_{s i}-\text { Fuzzy Lag } \operatorname{La}_{s i}\right\}
$$

where FN is a fuzzy number and si is the successor activity so that $i$ take values depending on the number of successors.

Add the fuzzy number calculated with fuzzy addition to the corresponding late time of the predecessor activity. If the dependency is SS, SF, FF, or FS, the fuzzy late times are calculated as follows:

$$
\begin{aligned}
& \text { If relation is SS: } F L S_{p i}=F L S_{s i}+F N_{s i} \\
& \text { If relation is SF: } F L S_{p i}=F L F_{s i}+F N_{s i} \\
& \text { If relation is FF: } F L F_{p i}=F L F_{s i}+F N_{s i} \\
& \text { If relation is FS: } F L F_{p i}=F L S_{s i}+F N_{s i} \\
& \text { Finally, } F L S x=F L F_{x}-F d_{x}
\end{aligned}
$$

where $\mathrm{FLF}_{\mathrm{x}}$ is the fuzzy late finish of activity $\mathrm{x}$, and $\mathrm{Fd}_{\mathrm{x}}$ is the fuzzy duration of activity $\mathrm{x}$.

\section{Total Float Calculation}

Once forward path and backward path calculations are finished, it is possible to calculate total float. The fuzzy total float for a given activity can be calculated as follows:

$$
F T F_{x}=F L F_{x}-F E F_{x} \text { or } F L S_{x^{-}} F E S_{x}
$$

where FTF $\mathrm{x}$ is the fuzzy total float of activity $\mathrm{x}$.

\section{Step 2: F-LOB Calculations}

Analysis of LOB with fuzzy sets is the second step in this model. The objective of LOB formulation is to achieve a resource-balanced schedule by determining the number of crews to be employed in each repetitive activity. When there are uncertainties associated with the duration of project activities, the determination of the number of crews and the progress rate is not as obvious as in the case of a certain environment. The developed model can solve this problem and has the ability to determine the number of crews and the progress rate as follows:

It is possible to formulate a strategy for meeting a prespecified project deadline. The desired rate of delivery $(\mathrm{Rd})$ 
is the theoretical rate of output that can be specified according to Fig. (1) and Eq. (17) as follows:

$$
R_{d}=\frac{N-1}{T_{p}-D F T_{1}}
$$

where $\mathrm{N}$ is the number of repetitive units; $\mathrm{T}_{\mathrm{p}}$ is the desired project duration; and $\mathrm{DFT}_{1}$ is the F-CPM duration of unit 1 .

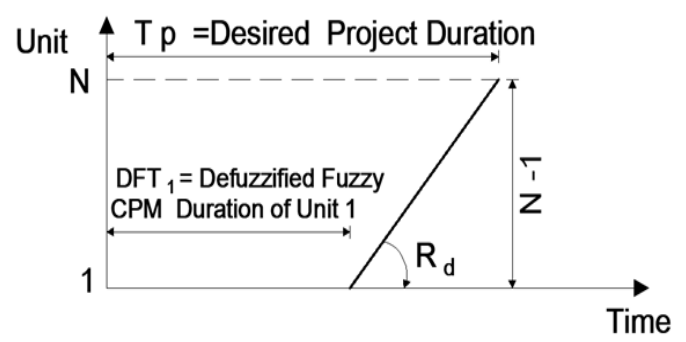

Figure 1: Desired Project Rate of Delivery.

The total float of non-critical activities are utilized to reduce the fuzzy number of crews employed using Eq. (18).

$$
R_{d i}=\frac{N-1}{T p-D F T 1+D F T F i}
$$

where $\mathrm{R}_{\mathrm{di}}$ is the desired (theoretical) rate of delivery of activity $\mathrm{i}, \mathrm{DFT}_{1}$ is the defuzzified fuzzy CPM duration of unit one and $\mathrm{DFTF}_{\mathrm{i}}$ is its defuzzified fuzzy total float calculated from the network of the first unit.

The fuzzy number of crews required to maintain a project rate of delivery can be calculated with reference to Fig. (2) and using Eq. (19).

$$
F C_{d i}=F d_{i} \times R_{d i}
$$

where $\mathrm{FC}_{\mathrm{di}}$ is the desired (theoretical) fuzzy number of crews and $F_{d i}$ is the fuzzy duration of activity $i$.

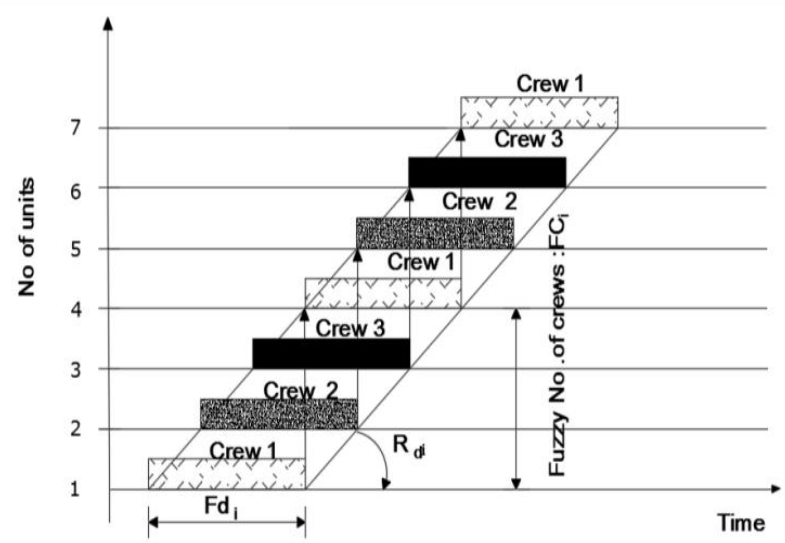

Figure 2: Synchronization and Work Continuity of Crews.

Then, to determinate the fuzzy actual number of crews the defuzzified fuzzy theoretical number of crews should be calculated using geometric centroid (C), which can be calculated as following:
Trapezoidal fuzzy number:

$$
C=\frac{-a^{2}-b^{2}+c^{2}+d^{2}-a b+c d}{3(-a-b+c+d)}
$$

Triangular fuzzy number: $C=\frac{\boldsymbol{a}+\boldsymbol{b}+\boldsymbol{c}}{3}$

where a, b,c and d are the fuzzy parameters.

In general, the defuzzified fuzzy theoretical number of crews calculated using Eq. (20.a) or (20.b) is not integer value and fractional crews are not possible so, the defuzzified fuzzy theoretical number of crews must be rounded up to determine the defuzzified fuzzy actual number of crews as given by Eq. (21.a). To ensure that the actual fuzzy number of crews allocated to an activity using Eq. (21.a) does not exceed available crews of that activity using Eq. (21.b).

$$
D F C_{a i}=\text { rounded up }\left(D F C_{d i}\right)
$$

where $\mathrm{DFC}_{\mathrm{ai}}$ is the Defuzzified fuzzy actual number of crews and $\mathrm{DFC}_{\mathrm{di}}$ is the Defuzzified fuzzy desired number of crews.

$$
D F C_{a i} \leq C_{m i}
$$

where $C_{m i}$ is the maximum available crews.

The fuzzy actual progress rates for different activities can be calculated using Eq. (22).

$$
F R_{a i}=D F C_{a i} / F d_{i}
$$

where $\mathrm{FR}_{\mathrm{ai}}$ is the fuzzy actual progress rate of activity $i$ and $\mathrm{Fd}_{\mathrm{i}}$ is the fuzzy duration of activity $\mathrm{i}$.

Finally, to determine the relationships between activities (SS or FF) and draw the LOB diagram, the horizontal distance between the start time of the last unit and the start time of the first unit for activity $\mathrm{i}\left(\Delta \mathrm{S}_{\mathrm{i}}\right)$ should be specified using the Eq. (23).

$$
F \Delta S_{i}=F S T_{N i}-F S T_{1 i}=(N-1) / F R_{a i}
$$

where $\mathrm{FST}_{\mathrm{Ni}}$ is the fuzzy start time of the last unit for activity $\mathrm{i}, \mathrm{FS}_{\mathrm{T} 1} \mathrm{i}$ is the fuzzy start time of the first unit for activity $i$ and $F \Delta S_{i}$ is the horizontal distance of the fuzzy start time between the last and first unit.

\section{Step 3: Activity Duration along all Units}

In this paper, the duration of each activity is assumed constant in all units of a repetitive activity. Having the basic LOB calculations performed, the duration of activity $i$ for all units can be calculated by Eq. (24) as shown in Fig. (3).

$$
F D_{i}=F d_{i}+\left(F S T_{i N}-F S T_{i 1}\right)=F d_{i}+F \Delta S=F d_{i}+(N-1) / F R_{a i}
$$


where, $\mathrm{FD}_{\mathrm{i}}$ is the fuzzy duration of activity $\mathrm{i}$ for all units.

\section{Step 4: Specifying Logical Relationships Using Overlapping Activities}

The logical dependency relationships among different activities can be specified according to the horizontal distance between the start times of the last unit and the start time of the first unit of each activity.

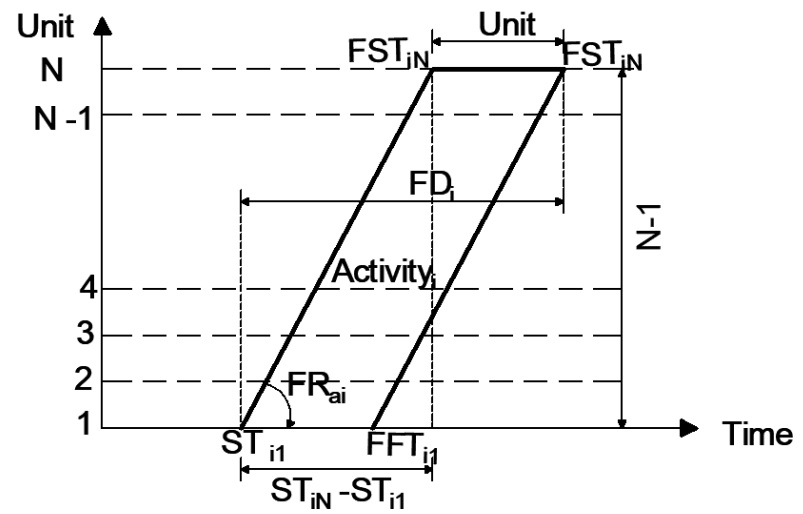

Figure 3: Duration of a Repetitive Activity along All Units.

To specify such relationships, the horizontal distance between the start times of the last unit and the start time of the first unit of each activity is compared with that of its successors. If $\Delta \mathrm{Si}$ and $\Delta \mathrm{Ss}$ denote the horizontal distance between the start time of the last unit and the start time of the first unit of activity $i$ and its succeeding activity $s$, respectively, three cases can be encountered.

\section{Case 1: $\mathbf{F} \Delta \mathbf{S}_{\mathrm{i}}<\mathbf{F} \Delta \mathbf{S}_{\mathrm{s}}$}

This shows the case of two diverging activities as depicted in Fig. (4), in which activity (i) is faster than its successor (s) (leading to divergence). In this case, the finish of the first unit of activity (i) controls the start of the first unit of activity (s). Thus, a start-to-start (SS) relationship can be specified. The lag associated with the (SS) relationship can be calculated by Eq. (25).

$$
\operatorname{Lag}_{s s}=d_{i}+B_{i s}
$$

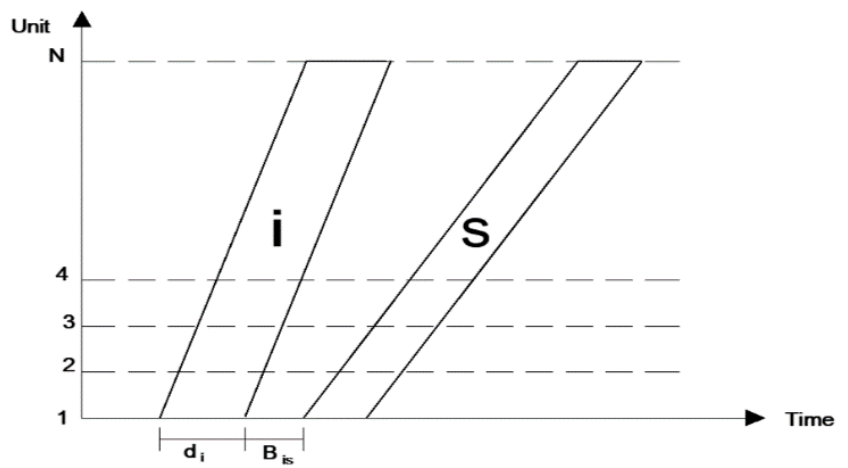

Figure 4: Overlapping Repetitive Activities with (SS) Relationship. where $\operatorname{Lag}_{\mathrm{ss}}$ is the lag associated with the start-to-start relationship between two activity $i$ and $s$; di is the duration of activity $\mathrm{i}$, and $\mathrm{B}_{\mathrm{is}}$ is the minimum buffer time between activities $i$ and $s$.

Buffer time is usually used in LOB scheduling to absorb the effect of any unforeseen effects that may delay project completion.

\section{Case 2: $\mathbf{F} \Delta \mathbf{S}_{\mathrm{i}}>\mathbf{F} \Delta \mathbf{S}_{\mathrm{s}}$}

This represents the case of two converging activities as shown in Figure (5), in which activity $s$ is faster than its predecessor $\mathrm{i}$ (leading to convergence). In this case, the finish of the last unit of activity i controls the start of the last unit of activity s. Thus, a finish-to-finish (FF) relationship can be specified. The lag associated with the (FF) relationship can be calculated by Eq. (26).

$$
\operatorname{Lag}_{f f}=d_{s}+B_{i s}
$$

where $\operatorname{Lag}_{\text {ff }}$ is the lag associated with finish-to-finish relationship between two activity $i$ and $s ; d_{s}$ is the duration of activity $\mathrm{s}$; and $\mathrm{B}$ is is the minimum buffer time between activities $\mathrm{i}$ and $\mathrm{s}$.

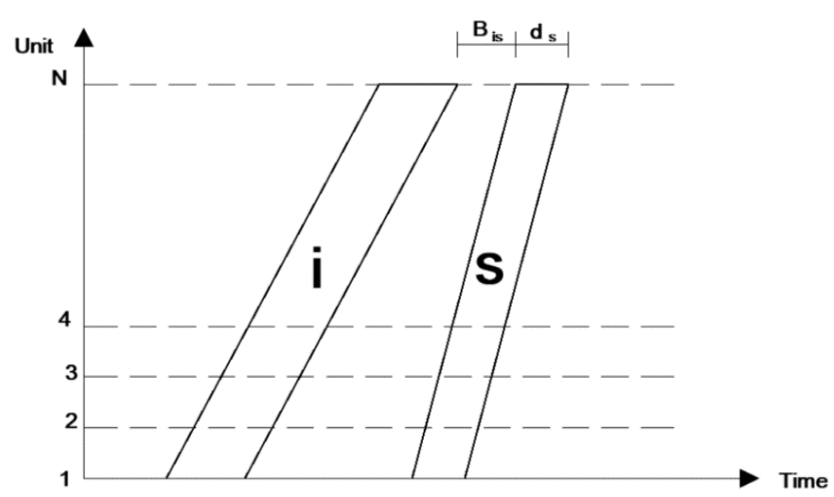

Figure 5: Overlapping Repetitive Activities with (FF) Relationship

\section{Case 3: $F \Delta S_{i}=F \Delta S_{s}$}

In this case, either an SS or FF relationship can be existed, taken by lag values as in cases 1 and 2 .

\section{Step 5: Integrated Time Scheduling}

Having CPM with fuzzy calculations performed, LOB with fuzzy calculations performed, the duration of the activity along all units calculated and the relationship type among consecutive activities specified with their associated lags, integrated time analysis similar to that of CPM can be easily done. Forward path calculations are done to determine early timings of activities, while late timings of activities are determined in the backward path calculations.

\section{A. Forward Path Calculations}

In forward path calculations, early timings (belong to the first and last units only) are determined for each activity i as follows:

\section{Case of (SS) relationship}




$$
F E S_{i 1}=\operatorname{Max}\left(F E S_{p 1}+\operatorname{Lagss}_{(i p)}\right), \quad p=1,2, \ldots . N_{P i}
$$

where $\mathrm{FES}_{\mathrm{i} 1}$ is the fuzzy early start of the first unit of

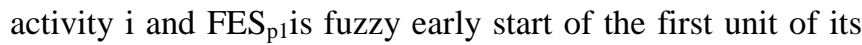
predecessor $\mathrm{p}$.

$$
F E F_{i N}=F E S_{i 1}+F D_{i}
$$

where $\mathrm{EF}_{\mathrm{iN}}$ is the early finish of the last unit of activity $i$ and $\mathrm{D}_{\mathrm{i}}$ the fuzzy duration of activity $i$ for all units.

\section{Case of (FF) relationship}

$$
F E F_{i N}=\operatorname{Max}\left(F E F_{p N}+\operatorname{Lagff}_{(i p)}\right), \quad p=1,2, \ldots . N_{P i}
$$

where $\mathrm{EF}_{\mathrm{iN}}$ is the fuzzy early finish of the last unit of activity $\mathrm{i} ; \mathrm{EF}_{\mathrm{pN}}$ is fuzzy early finish of the last unit of its predecessor p.

$$
F E S_{i l}=F E F_{i N}-F D_{i}
$$

where $\mathrm{FES}_{\mathrm{i} 1}$ is the fuzzy early start of the first unit of activity $\mathrm{i} ; \mathrm{FEF}_{\mathrm{iN}}$ is the fuzzy early finish of the last unit of activity $\mathrm{i}$; and $F D_{\mathrm{i}}$ the fuzzy duration of activity $\mathrm{i}$ for all units.

Having the early start and finish times of the first and last units of activity i determined, the early start and finish times for all units of that activity can be easily determined using Equations (31) and (32).

$$
F E S_{\text {in }}=F E S_{i 1}+(n-1) / F R_{a i}
$$

where FESin is the fuzzy early start of any unit $n$ in activity $i$ and $\mathrm{FES}_{\mathrm{i} 1}$ is the fuzzy early start of the first unit of activity $i$, $(\mathrm{n}=1,2, \ldots \mathrm{N})$.

$$
F E F_{\text {in }}=F E S_{\text {in }}+F d_{i}
$$

Where $\mathrm{FEF}_{\text {in }}$ is the fuzzy early finish of any unit $\mathrm{n}$ in activity $\mathrm{i} ; \mathrm{FES}_{\mathrm{i} 1}$ is the fuzzy early start of the first unit of activity $\mathrm{i}$; and $\mathrm{Fd}_{\mathrm{i}}$ is the fuzzy duration of activity $i$.

\section{B. Backward Path Calculations}

In backward path calculations, the late timings (belong to the first and last units only) are determined for each activity $i$ as follows:

\section{Case of (SS) relationship}

$$
F L S_{i l}=\operatorname{Min}\left(F L S_{s 1^{-}} \operatorname{Lag} s S_{(i s)}\right), s=1,2, \ldots . N_{S i}
$$

where FLS ${ }_{\mathrm{i} 1}$ is the fuzzy late start of the first unit of activity $\mathrm{i} ; \mathrm{FLS}_{\mathrm{s} 1}$ is fuzzy late start of the first unit of its successor s.

$$
F L F_{i N}=F L S_{i l}+F D_{i}
$$

Where $F F_{i N}$ is the fuzzy late finish of the last unit of activity $i$ and $\mathrm{FD}_{\mathrm{i}}$ the fuzzy duration of activity $i$ for all units.

\section{$\underline{\text { Case of }(\mathrm{FF}) \text { relationship }}$}

$\mathrm{FLF}_{\mathrm{iN}}=\operatorname{Min}\left(\mathrm{FLF}_{\mathrm{sN}}-\operatorname{Lag} \mathrm{ff}(\right.$ is $), \mathbf{s}=1,2, \cdots . \mathrm{N}_{\mathrm{Si}}$

where $\mathrm{FLF}_{\mathrm{iN}}$ is the fuzzy late finish of the last unit of activity $\mathrm{i} ; \mathrm{FLF}_{\mathrm{sN}}$ is fuzzy late finish of the last unit of its successor $\mathrm{s}$.

$$
F L S_{i l}=F L F_{i N}-F D_{i}
$$

where FLS $S_{11}$ is the fuzzy late start of the first unit of activity $\mathrm{i} ; \mathrm{FLF}_{\mathrm{iN}}$ is the fuzzy late finish of the last unit of activity $\mathrm{i}$; and $\mathrm{FD}_{\mathrm{i}}$ the fuzzy duration of activity $i$ for all units.

Having the late start and finish times of the first and last units of activity i determined, the late start and finish times for all units of that activity can be easily determined using Equation (37) and (38).

$$
F L F_{\text {in }}=F L F_{i 1}+(n-1) / F R_{a i}
$$

where $F L F_{i n}$ is the fuzzy late finish of any unit $n$ in activity $i$ and $\mathrm{FLF}_{\mathrm{i} 1}$ is the fuzzy late finish of the first unit of activity $i$ $(n=1,2, N)$.

$$
F L S_{\text {in }}=F L F_{\text {in }}-F_{d i}
$$

where $\mathrm{FLS}_{\mathrm{in}}$ is the fuzzy late start of any unit $\mathrm{n}$ in activity $\mathrm{i}$; FLFi1 is the fuzzy late finish of the first unit of activity $i$; and $F d_{i}$ is the fuzzy duration of activity $i$.

\section{Model Automation}

Real-life projects are characterized by a large number of activities. To facilitate the use of the developed model presented in the previous section to schedule such kinds of projects, an automated system called (F.CPM.LOB) is developed. This section provides details of the automated system used for the implementation of the developed model (F.CPM.LOB). The system is automated using commercial software (Microsoft Excel and Visual Basic Programming Language). The automated system consists of six sheets:

(1) The first sheet (Datasheet) is used for project data entry and to perform (F.CPM.LOB) calculations using Microsoft Excel. Microsoft Excel is programmed using Visual Basic for Application (VBA).

(2) The second sheet (F-CPM sheet); is used to calculate the activities' fuzzy times and fuzzy floats (FES, FEF, FLS, FLF, and FTF) and fuzzy project duration of unit one.

(3) The third sheet (F-LOB sheet); is used to calculate the fuzzy progress rate for each activity and the total fuzzy duration for each activity along all units.

(4) The fourth sheet (DFLOB sheet); is used to calculate the defuzzified fuzzy progress rate and the defuzzified fuzzy project duration for each activity along all units to determine the logical relationships between activities.

(5) The fifth sheet (Relationships sheet); is used to determine logical relationships between activities and calculate associated lag.

(6) The sixth sheet (DFCPM-Analysis sheet); is used to calculate the activities' defuzzified fuzzy times and defuzzified fuzzy total float (DFES, DFEF, DFLS, 
DFLF, and DFTF) and the total project duration for all units.

For data entry, the user opens Microsoft Excel (2010). After opening the program, the user should press on the button (Enter Data) as shown in Fig. (6).

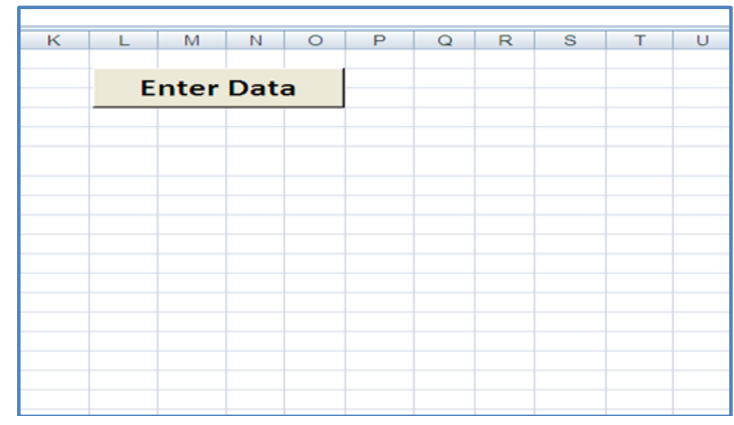

Figure 6: Interface of Automated System.

A case study will be presented in the next section to illustrate the applicability of the developed model to real life projects.

\section{CASE STUDY}

The case study is City Stars North Coast which is one of the latest and best tourist villages that have been launched in the northern coast on the Gulf of Ras al-Hikma It is located at Kilo 199 Alexandria Matrouh Road after La Vista North Coast village and before Mountain View North Coast village in Ras El Hekma area.

The construction in this project consists of cabins, chalets and villas. The construction of villas consist of 3 sectors; first sector is including 36 villas, second sector is including 24 villas and last, third sector is including 7 villas. The case study will include the first sector only, which is consisting of 36 villas. The project date start from 1st November 2017 to 1st July 2018, 18 villas will deliver each 4 months. So, the first group which including villas $(1: 18)$ will start from 1st November 2017 to 1st March 2018 and the second group which including villas (19:36) will start from 1st March 2018 to 1st July 2018.

\section{A. Project Data}

The project is divided into 20 activities. Estimating a precise duration for project activities is unrealistic because of many factors that effect on project duration. Changing in production rate of crews and weather conditions are examples for these factors. Table (1) shows durations used for risk analysis of time estimate for three selected activities.

The duration of activities is represented by three estimates (minimum, normal, maximum) durations. Triangular fuzzy number $(a, b, c)$ is used to best fit these three estimates. The minimum duration can be represented by (a) parameter, the normal duration can be represented by (b) parameter and the maximum duration can be represented by (c) parameter. In this case, the user enters Dur (b) = Dur (c). Table (2) shows project activities with their fuzzy duration, lags, and predecessors.

F.CPM.LOB program is used to schedule this project. After project data in Table (2) are input, the user can perform scheduling.

Table 1: Durations used for risk analysis for time estimate of three selected activities

\begin{tabular}{|c|c|c|c|c|c|}
\hline \multirow{2}{*}{ ID } & \multirow{2}{*}{ Activity } & \multirow{2}{*}{ Risk Factor } & \multicolumn{3}{|c|}{ Duration(day) } \\
\hline & & & Min & Normal & Max \\
\hline \multirow{3}{*}{ A02 } & \multirow{3}{*}{ Foundation } & $\begin{array}{c}\text { Different } \\
\text { Production }\end{array}$ & \multirow{3}{*}{10} & \multirow{3}{*}{12} & \multirow{3}{*}{13} \\
\hline & & Rate of Crews & & & \\
\hline & & $\begin{array}{l}\text { Weathering } \\
\text { Conditions }\end{array}$ & & & \\
\hline \multirow[t]{2}{*}{ A06 } & \multirow{2}{*}{$\begin{array}{l}\text { Construct } \\
\text { Ground } \\
\text { Slab }\end{array}$} & $\begin{array}{c}\text { Different } \\
\text { Production } \\
\text { Rate of Crews }\end{array}$ & \multirow[t]{2}{*}{6} & \multirow[t]{2}{*}{8} & \multirow[t]{2}{*}{10} \\
\hline & & $\begin{array}{l}\text { Weathering } \\
\text { Conditions }\end{array}$ & & & \\
\hline \multirow{3}{*}{ A03 } & \multirow{3}{*}{$\begin{array}{l}\text { Construct } \\
\text { Ground } \\
\text { Column }\end{array}$} & $\begin{array}{c}\text { Different } \\
\text { Production }\end{array}$ & \multirow{3}{*}{3} & \multirow{3}{*}{4} & \multirow{3}{*}{5} \\
\hline & & Rate of Crews & & & \\
\hline & & $\begin{array}{l}\text { Weathering } \\
\text { Conditions }\end{array}$ & & & \\
\hline
\end{tabular}

\section{B. Scheduling Data}

Fuzzy CPM calculations (fuzzy times and floats of project's activities) are given in Table (3). Table (4) shows Fuzzy LOB calculations (Actual number of crews, actual progress rate, the horizontal distance between the start time of the last unit and the start time of the first unit, and the total duration of activities along all units). In Table(4), for activity (A01), the desired rate of delivery can be calculated using Eq.(18) to be 0.44 , the fuzzy number of crews required to maintain a project rate of delivery can be calculated using Eq.(19) to be $(0.87,0.87,0.87)$, then, the defuzzified fuzzy theoretical number of crews should be calculated using Eq. (20.b) to be 0.87 . The defuzzified fuzzy actual number of crews should be calculated using Eq. (21.a) to be 1.00. The fuzzy actual progress rate activity can be calculated using Eq. (22) to be $(0.50,0.50,0.50)$. The horizontal distance between the start time of the last unit and the start time of the first unit for activity (A01) should be specified using the Eq. (23) to be $(34.00,34.00,34.00)$. Finally, the fuzzy duration of activity (A01) for all units can be calculated by Eq. (24) to be (36.00, 36.00, 36.00).

Table (5) shows the DF-LOB calculations. For activity (A01), the defuzzified fuzzy duration, the defuzzified fuzzy actual number of crews, the defuzzified fuzzy actual progress rates, The defuzzified fuzzy horizontal distance between the start time of the last unit and the start time of the first unit for activity (A01) and the defuzzified fuzzy duration of activity (A01) for all units can be calculated by Eq. (20.b). The relationships between activities and associated lag are given in Table (6). For example, activity (A02) is a successor to activity (A01). In this scenario, $\mathrm{DF} \Delta \mathrm{S}_{(\mathrm{A} 01)}=34.00$ and $\mathrm{DF} \Delta \mathrm{S}_{(\mathrm{A} 02)}=33.06$, and therefore an FF relationship exists between activities (A01) and (A02), and the corresponding $\operatorname{Lag}_{\mathrm{FF}}=11.67$ days. 
Finally, DFCPM analysis is given in Table (7). For example, in the forward path, activity (A01) has defuzzified activity duration equal to 36.00 , therefore, the defuzzified fuzzy early start can be calculated by Eq. (27) to be 00.00 . The defuzzified fuzzy early finish of activity (A01) can be calculated by Eq. (28) to be 36.00. In the backward path, activity (A10) has defuzzified fuzzy duration equal to 38.00 and its predecessor is activity (A08) and the relation between them is SS with $\mathrm{Lag}=4.00$, therefore, the defuzzified fuzzy late start can be calculated using Eq. (33) to be 73.89 and the defuzzified fuzzy late finish can be calculated using Eq. (34) to be 111.89 .

The project is divided into two stages. In the first stage 18 villas delivered after 4 months which equals 120 days. Therefore, the total project duration of the first stage is 120 days. From scheduling, the fuzzy project duration of one unit equals $(69,82,82,92)$ and the critical path is (A01-A02A03-A04-A05-A06-A07-A09-A11-A14).

After applying LOB calculations, the total defuzzified fuzzy project duration equals (116.89) days which is less than the duration of the contract and the critical path is (A01A02-A03-A04-A05-A06-A07-A09-A11-A14).

Table 2: Planning Data of City Star Al Sahel Project.

\begin{tabular}{|c|c|c|c|c|}
\hline ID & Activity Name & $\begin{array}{c}\text { Fuzzy } \\
\text { Durations } \\
\text { (days) }\end{array}$ & $\begin{array}{c}\text { Predecesso } \\
\text { rs }\end{array}$ & $\begin{array}{l}\text { Lags } \\
\text { (days) }\end{array}$ \\
\hline A01 & Excavation & $(2,2,2)$ & & \\
\hline A02 & Foundation & $(10,12,13)$ & A01 & \\
\hline A03 & $\begin{array}{l}\text { Construct } \\
\text { Ground Column }\end{array}$ & $(3,4,5)$ & A02 & \\
\hline A04 & $\begin{array}{l}\text { Bitumen\& Wall } \\
\text { thick(25)cm } \\
\text { under S.O.G \& } \\
\text { Backfilling }\end{array}$ & $(4,4,4)$ & A03 & \\
\hline A05 & Slab on Grade & $(1,2,3)$ & A04 & \\
\hline A06 & $\begin{array}{c}\text { Construct } \\
\text { Ground Slab }\end{array}$ & $(6,8,10)$ & A05 & \\
\hline A07 & $\begin{array}{l}\text { Construct First } \\
\text { Floor }\end{array}$ & $(9,12,14)$ & A06 & $(7,7,7)$ \\
\hline A08 & $\begin{array}{l}\text { Brick Walls for } \\
\text { Ground Floor }\end{array}$ & $(4,4,4)$ & A07 & \\
\hline A09 & $\begin{array}{c}\text { Construct } \\
\text { Second Floor }\end{array}$ & $(9,12,14)$ & A07 & $(7,7,7)$ \\
\hline A10 & $\begin{array}{l}\text { Brick Walls for } \\
\text { First Floor }\end{array}$ & $(4,4,4)$ & A08 & \\
\hline A11 & Construct Roof & $(3,4,5)$ & A09 & $(7,7,7)$ \\
\hline A12 & $\begin{array}{l}\text { Brick Walls for } \\
\text { Second Floor }\end{array}$ & $(4,4,4)$ & $\mathrm{A} 09, \mathrm{~A} 10$ & \\
\hline A13 & $\begin{array}{c}\text { Brick Walls for } \\
\text { Roof }\end{array}$ & $(1,1,1)$ & A11,A12 & \\
\hline A14 & $\begin{array}{c}\text { Thermal } \\
\text { Insulation }\end{array}$ & $(1,1,1)$ & A11 & \\
\hline
\end{tabular}

Table 3: Activities and their Fuzzy Times and Floats of City Star Al Sahel Project.

\begin{tabular}{|c|c|c|c|c|c|c|c|c|c|c|c|c|c|c|}
\hline$\vec{\nabla}$ & 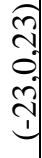 & 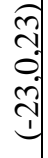 & 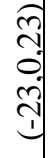 & 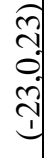 & 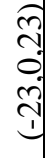 & $\begin{array}{l}\text { กิ } \\
0 \\
\text { กิ } \\
\text { गे }\end{array}$ & તิ- & 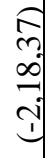 & 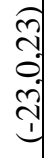 & 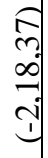 & 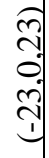 & 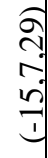 & 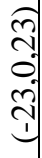 & 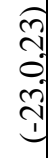 \\
\hline$\sqrt{2}$ & 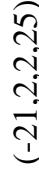 & 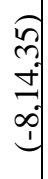 & 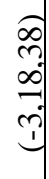 & 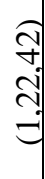 & 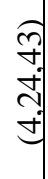 & $\begin{array}{l}a \\
\text { f } \\
\text { गे } \\
\pm \\
\Xi\end{array}$ & $\begin{array}{l}\sqrt{6} \\
\sqrt{n} \\
n \\
0\end{array}$ & $\begin{array}{l}\hat{0} \\
\text { nీ} \\
\hat{0} \\
\hat{0}\end{array}$ & $\begin{array}{l}0 \\
0 \\
0 \\
0 \\
0 \\
0\end{array}$ & 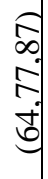 & $\begin{array}{l}0 \\
\vec{a} \\
\infty \\
\infty \\
0\end{array}$ & $\begin{array}{l}\vec{\sigma} \\
\infty \\
\infty \\
\infty\end{array}$ & 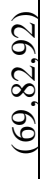 & $\begin{array}{l}\text { तू } \\
\text { ते } \\
\text { ô. } \\
\text { فे }\end{array}$ \\
\hline$\frac{2}{1}$ & 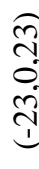 & $\begin{array}{l}\text { הิ } \\
\text { ㄱ. } \\
\text { ㄱ. }\end{array}$ & 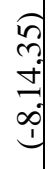 & 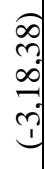 & 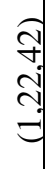 & 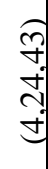 & 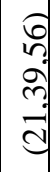 & $\begin{array}{l}\text { จे } \\
\text { aे } \\
0 \\
0 \\
0\end{array}$ & 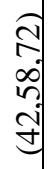 & 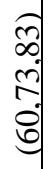 & 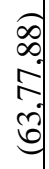 & 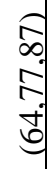 & $\begin{array}{l}\vec{a} \\
\vec{a} \\
\infty \\
\infty \\
0 \\
0\end{array}$ & $\begin{array}{l}0 \\
0 \\
\infty \\
\infty \\
0\end{array}$ \\
\hline$\underline{T}$ & तิ & 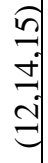 & 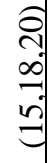 & 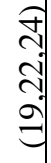 & 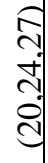 & 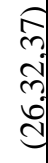 & 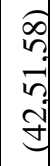 & 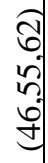 & $\begin{array}{l}2 \\
0 \\
0 \\
\infty \\
0 \\
0\end{array}$ & $\begin{array}{l}0 \\
8 \\
0 \\
0 \\
0 \\
0\end{array}$ & $\begin{array}{l}\vec{\sigma} \\
\bar{\sigma} \\
\infty \\
0 \\
0\end{array}$ & 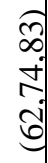 & 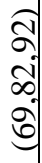 & 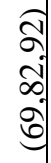 \\
\hline శ్ & $\begin{array}{l}\text { 0. } \\
0 \\
\stackrel{0}{0}\end{array}$ & $\begin{array}{l}\text { הี } \\
\text { ปิ }\end{array}$ & 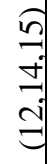 & 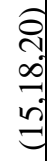 & 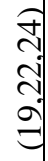 & 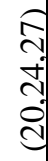 & 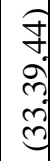 & 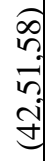 & $\begin{array}{l}\tilde{ే} \\
\infty \\
n \\
a \\
\text { y }\end{array}$ & $\begin{array}{c}\text { สิ } \\
n \\
n \\
0 \\
0\end{array}$ & 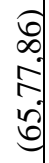 & $\begin{array}{l}\text { a } \\
0 \\
0 \\
\infty \\
0 \\
0\end{array}$ & $\begin{array}{l}\vec{a} \\
\overrightarrow{0} \\
\infty \\
\infty \\
0 \\
0\end{array}$ & $\begin{array}{l}0 \\
0 \\
\infty \\
\infty \\
0\end{array}$ \\
\hline 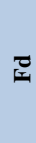 & הิ & 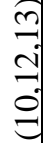 & $\begin{array}{l}n \\
+ \\
\dot{0} \\
0\end{array}$ & $\begin{array}{l}\vec{f} \\
\dot{f} \\
\dot{v}\end{array}$ & $\widetilde{3}$ & $\begin{array}{c}0 \\
\infty \\
0 \\
0\end{array}$ & $\frac{\partial}{\mathrm{d}}$ & $\begin{array}{l}\vec{f} \\
\dot{f} \\
\dot{y}\end{array}$ & 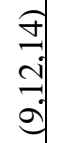 & $\begin{array}{l}f \\
\dot{f} \\
\dot{f}\end{array}$ & $\begin{array}{l}n \\
+ \\
0\end{array}$ & $\begin{array}{l}\vec{\nabla} \\
\dot{\nabla} \\
\dot{v}\end{array}$ & $=$ & $=$ \\
\hline Я & $\stackrel{8}{4}$ & 이 & ชి & $\stackrel{+}{4}$ & 8 & 8 & 包 & $\underset{4}{\infty}$ & 8 & $\underset{8}{\gtrless}$ & $\underset{Z}{Z}$ & $\frac{1}{4}$ & $\frac{m}{4}$ & $\underset{\square}{ \pm}$ \\
\hline
\end{tabular}

\section{CONCLUSIONS}

The scheduling of repetitive construction projects under uncertainty problem is discussed. Classical CPM analysis does not suit characteristics for repetitive projects, whereas LOB lacks the analytical qualities of CPM scheduling. Different techniques are used for solving the problem of uncertainty such as fuzzy set theory. In this paper, an integrated CPM and LOB with Fuzzy set theory for scheduling repetitive construction projects have been developed to combine the benefits of both CPM and LOB with fuzzy theory in an easy analytical non-graphical manner.

To simplify the use of the developed model, an automated system called (F.CPM.LOB) was developed. The system is automated using commercial software (Microsoft Excel and Visual Basic Programming Language). The program provides calculations of critical path method with fuzzy, Line of Balance with fuzzy, calculating activity 
duration along all repetitive units, specifying logical relationships and associated lag using overlapping activities, and finally, DFCPM time analysis.

Table 4: Fuzzy Line of Balance Calculations of City Star Al Sahel Project.

\begin{tabular}{|c|c|c|c|c|c|c|c|c|c|c|c|c|c|c|}
\hline |ิ & 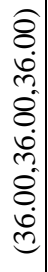 & 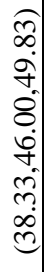 & 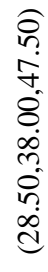 & 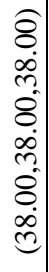 & 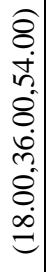 & 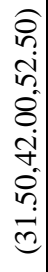 & $\begin{array}{l}\widehat{6} \\
\dot{n} \\
n \\
0 \\
8 \\
\dot{0} \\
+ \\
\dot{0} \\
n \\
\dot{n} \\
\dot{d}\end{array}$ & 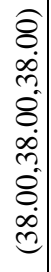 & $\begin{array}{l}\hat{\sigma} \\
\dot{0} \\
n \\
8 \\
0 \\
\dot{0} \\
+ \\
0 \\
n \\
\dot{n} \\
\tilde{c}\end{array}$ & 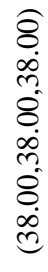 & 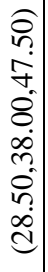 & 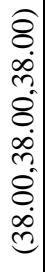 & 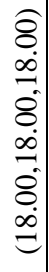 & $\begin{array}{l}\widehat{8} \\
0 \\
\infty \\
0 \\
8 \\
0 \\
0 \\
0 \\
0 \\
0 \\
0\end{array}$ \\
\hline$\frac{2}{10}$ & 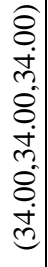 & 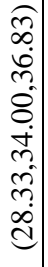 & 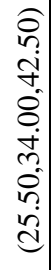 & 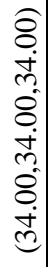 & 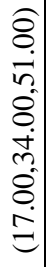 & 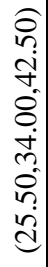 & 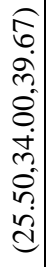 & $\begin{array}{l}\hat{\delta} \\
\dot{+} \\
\dot{m} \\
\dot{8} \\
\dot{0} \\
\dot{+} \\
\dot{8} \\
\dot{8} \\
\dot{0}\end{array}$ & 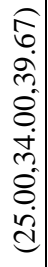 & 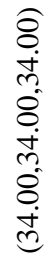 & 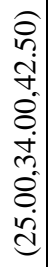 & 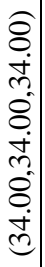 & 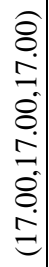 & 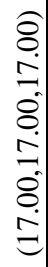 \\
\hline$\frac{\pi}{\Sigma}$ & 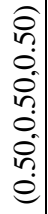 & $\begin{array}{c}\hat{\theta} \\
\dot{0} \\
0 \\
0 \\
n \\
0 \\
0 \\
0 \\
\dot{0} \\
\dot{e}\end{array}$ & $\begin{array}{l}\hat{\sigma} \\
0 \\
0 \\
0 \\
0 \\
0 \\
0 \\
? \\
0\end{array}$ & $\begin{array}{l}0 \\
n \\
0 \\
0 \\
0 \\
0 \\
0 \\
0 \\
n \\
e \\
0\end{array}$ & $\begin{array}{c}\widehat{8} \\
0 \\
\dot{0} \\
n \\
0 \\
\text { m. } \\
\tilde{e} \\
e\end{array}$ & $\begin{array}{l}\widehat{\hat{b}} \\
\dot{0} \\
0 \\
0 \\
0 \\
0 \\
0 \\
\dot{0} \\
\dot{0}\end{array}$ & 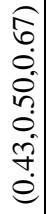 & $\begin{array}{l}0 \\
0 \\
0 \\
0 \\
0 \\
n \\
0 \\
0 \\
0 \\
0 \\
0\end{array}$ & $\begin{array}{l}\hat{\sigma} \\
\dot{0} \\
0 \\
0 \\
0 \\
0 \\
\stackrel{0}{0} \\
\dot{e}\end{array}$ & 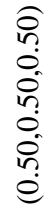 & $\begin{array}{l}\widehat{\hat{b}} \\
\dot{0} \\
0 \\
0 \\
0 \\
0 \\
0 \\
+ \\
\dot{0} \\
\dot{0}\end{array}$ & $\begin{array}{c}\widehat{D} \\
n \\
0 \\
0 \\
n \\
0 \\
0 \\
0 \\
n \\
e \\
e\end{array}$ & 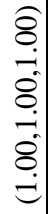 & $\begin{array}{l}8 \\
8 \\
8 \\
8 \\
8 \\
8 \\
8\end{array}$ \\
\hline 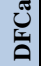 & -1 & 6 & $N$ & $N$ & - & $\nabla$ & 0 & $N$ & 0 & $N$ & $N$ & $N$ & -1 & - \\
\hline $\begin{array}{l}\text { Ũ } \\
\text { U. }\end{array}$ & $\begin{array}{l}0 \\
0 \\
0\end{array}$ & $\begin{array}{l}8 \\
\dot{n}\end{array}$ & $\stackrel{ \pm}{\stackrel{ \pm}{\leftrightarrows}}$ & $\underset{-}{ \pm}$ & $\begin{array}{c}\hat{\infty} \\
0 \\
0\end{array}$ & $\begin{array}{l}\stackrel{a}{.} \\
\dot{r}\end{array}$ & 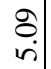 & กొ & $\begin{array}{l}8 \\
i n\end{array}$ & 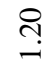 & $\underset{\Xi}{\stackrel{ \pm}{\Xi}}$ & $\stackrel{\substack{+\sim}}{.}$ & $\begin{array}{l}7 \\
0\end{array}$ & $\begin{array}{l}7 \\
0\end{array}$ \\
\hline ర్ల & $\begin{array}{c}\widehat{\sigma} \\
\infty \\
\dot{0} \\
\infty \\
\infty \\
\dot{0} \\
\hat{0} \\
\infty \\
\dot{e}\end{array}$ & $\begin{array}{c}\widehat{\sigma} \\
\mathfrak{n} \\
\tilde{n} \\
n \\
n \\
0 \\
n \\
\dot{t} \\
0\end{array}$ & 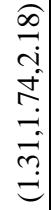 & 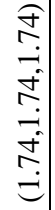 & $\begin{array}{c}\overparen{\sigma} \\
\tilde{-} \\
\hat{\infty} \\
\dot{0} \\
\dot{f} \\
\dot{f} \\
\dot{e}\end{array}$ & 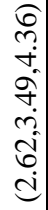 & 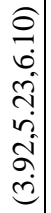 & 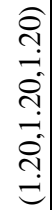 & 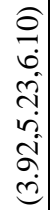 & 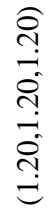 & 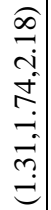 & 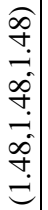 & $\begin{array}{l}f \\
f \\
0 \\
\dot{f} \\
\dot{f} \\
\dot{0} \\
\dot{f} \\
\dot{e}\end{array}$ & $\begin{array}{l}f \\
\dot{f} \\
0 \\
\dot{f} \\
\dot{0} \\
0 \\
\dot{f} \\
\dot{0}\end{array}$ \\
\hline$\approx$ & $\begin{array}{l}f \\
\dot{0}\end{array}$ & $\begin{array}{l}\forall \\
\dot{0}\end{array}$ & $\begin{array}{l}f \\
\dot{0}\end{array}$ & $\begin{array}{l}7 \\
0\end{array}$ & $\begin{array}{l}\text { J. } \\
0\end{array}$ & $\begin{array}{l}f \\
\dot{0}\end{array}$ & $\begin{array}{l}f \\
0 \\
0\end{array}$ & $\begin{array}{l}0 \\
\text { గొ }\end{array}$ & $\begin{array}{l} \pm \\
0\end{array}$ & గి & $\begin{array}{l}f \\
0\end{array}$ & $\tilde{n}$ & $\begin{array}{l}f \\
\dot{0}\end{array}$ & $\stackrel{7}{0}$ \\
\hline 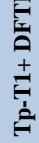 & $\begin{array}{l}8 \\
\dot{0} \\
\text { mे }\end{array}$ & $\begin{array}{l}8 \\
\text { ले } \\
\text { ले }\end{array}$ & $\begin{array}{l}8 \\
\text { ¿े. } \\
\text { ले }\end{array}$ & $\begin{array}{l}8 \\
\text { ஓे } \\
\text { ले }\end{array}$ & $\begin{array}{l}8 \\
8 \\
\text { mे }\end{array}$ & $\begin{array}{l}8 \\
\text { ఏे. } \\
\text { ले }\end{array}$ & $\begin{array}{l}\text { ¿े. } \\
\text { ळे }\end{array}$ & $\begin{array}{l}\hat{\sigma} \\
\dot{0} \\
n\end{array}$ & $\begin{array}{l}8 \\
\text { ஓे. } \\
\text { p. }\end{array}$ & $\begin{array}{l}\hat{\sigma} \\
\dot{0} \\
n\end{array}$ & $\begin{array}{l}8 \\
\text { ¿े. } \\
\text { m. }\end{array}$ & 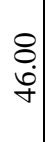 & $\begin{array}{l}8 \\
8 \\
\text { mे }\end{array}$ & $\begin{array}{l}8 \\
\text { ఏ. } \\
\text { ले. }\end{array}$ \\
\hline 留 & $\begin{array}{l}8 \\
0\end{array}$ & $\begin{array}{l}8 \\
0\end{array}$ & $\begin{array}{l}8 \\
0 \\
0\end{array}$ & $\begin{array}{l}8 \\
0\end{array}$ & $\begin{array}{l}8 \\
0 \\
0\end{array}$ & $\begin{array}{l}8 \\
0 \\
0\end{array}$ & $\begin{array}{l}8 \\
0\end{array}$ & $\begin{array}{l}\hat{6} \\
\mathbf{I}\end{array}$ & $\begin{array}{l}8 \\
0\end{array}$ & $\begin{array}{l}\hat{\sigma} \\
\tilde{I}\end{array}$ & 8 & $\begin{array}{l}8 \\
\end{array}$ & $\begin{array}{l}8 \\
0 \\
0\end{array}$ & $\stackrel{8}{0}$ \\
\hline 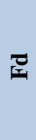 & 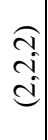 & 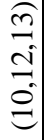 & $\begin{array}{l}\overparen{n} \\
\dot{f}_{0} \\
\dot{f}_{0} \\
\tilde{C}\end{array}$ & $\begin{array}{l}\overparen{f} \\
\dot{f} \\
\dot{f}\end{array}$ & 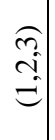 & $\begin{array}{l}\widehat{0} \\
\infty \\
0 \\
\hat{e}\end{array}$ & $\begin{array}{c}\frac{\partial}{J} \\
\vec{c} \\
\overrightarrow{0}\end{array}$ & $\begin{array}{l}\stackrel{f}{f} \\
f_{0} \\
\dot{J}\end{array}$ & $\begin{array}{c}\frac{\partial}{J} \\
\stackrel{\mathfrak{d}}{a} \\
0\end{array}$ & $\begin{array}{l}\stackrel{f}{f_{0}} \\
\dot{f}_{0}\end{array}$ & $\begin{array}{l}\tilde{n} \\
\dot{\sigma} \\
\tilde{c}\end{array}$ & $\begin{array}{l}\stackrel{f}{f_{0}} \\
\dot{J}_{0}\end{array}$ & $\begin{array}{l}\cong \\
\cong \\
\Xi\end{array}$ & $\begin{array}{l}= \\
= \\
=\end{array}$ \\
\hline I & $\bar{\alpha}$ & ô & 客 & \begin{tabular}{l}
0 \\
\multirow{2}{*}{}
\end{tabular} & $\stackrel{n}{2}$ & 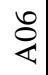 & $\stackrel{5}{2}$ & 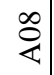 & $\frac{8}{2}$ & $\stackrel{0}{2}$ & $\bar{z}$ & $\frac{N}{2}$ & $\frac{m}{4}$ & $\underset{\square}{ \pm}$ \\
\hline
\end{tabular}

In order to verify the developed model, a real-life project City Stars North Coast project) was used. The automated system was used to simplify the calculations of the developed model. The results show the capability of the developed model to deal with the uncertainty inherent in construction projects in a sufficient manner and the ability to perform network schedule considering logical dependency constraints while satisfying work continuity and availability constraints. A case study was presented to validate the proposed model and to illustrate its use. The model can be particularly advantageous when the project has a large number of activities.

This study has successfully demonstrated the feasibility of applying fuzzy set theory to schedule repetitive construction projects. However, there is a number of potential improvements that could be made to the present study. Some of the most important concerns are:

(1) The model can be extended to consider the learning curve effect.

(2) The model can be extended to consider variable activity durations.

(3) The model can be extended to consider imposed work interruptions.

(4) The model can be extended to consider the cost of project activities (fuzzy cost).

\section{ACKNOWLEDGMENT}

Corresponding author wants to thank his supervisors for their valuable suggestions and help.

\section{REFERENCES}

[1] Abd El-Khalek, S.E. (2007) "Network Scheduling under Uncertainty in Construction Management.” M.Sc. Thesis, Tanta University, Tanta, Egypt.

[2] Adeli, H. and Karim, A. (1997). "Scheduling/Cost Optimization and Neural Dynamics Model for Construction." Journal of Construction Engineering and Management, Vol. 123, No. 4, PP. 450-458.

[3] Agrama, F.A. (2006). "The Line of Balance Technique by Genetic Optimization." Ph.D. Thesis, Tanta University, Tanta, Egypt.

[4] Al-Sarraj, Z. M. (1990). "Formal Development of Line of Balance Technique." Journal of Construction Engineering and Management, Vol. 116, No. 4, PP. 689704.

[5] Ammar, M. and Elbeltagi, E. (2001). "Algorithm for Determining Controlling Path Considering Resource Continuity." Journal of Computing in Civil Engineering, Vol. 15, No. 4, PP. 292-298.

[6] Ammar, M. (2007). "Optimization Modeling of LOB Scheduling Consideration Work Interruption." Proceeding of the 12th International Colloquium on Structural and Geotechnical Engineering, Ain-Shams University, Egypt.

[7] Ammar, M. (2013). "Lob and CPM Integrated Method for Scheduling Repetitive Projects." Journal of Construction Engineering and Management, Vol. 139, No. 1, PP. 44-50.

[8] Antill, J.M., Woodhead, R.W. (1990). "Critical Path Method in Construction Practice." Journal of 
Construction Engineering and Management, Vol. 132,

No. 7, PP. 712-722.

Table 5: Defuzzified Fuzzy Line of Balance Calculations of of City Star Al Sahel Project.

\begin{tabular}{|c|c|c|c|c|c|}
\hline ID & DFd & DFC $_{\mathbf{a}}$ & DFR $_{\mathbf{a}}$ & DF $\Delta \mathbf{S}$ & DFD \\
\hline $\mathrm{A} 01$ & 2.00 & 1.00 & 0.50 & 34.00 & 36.00 \\
\hline $\mathrm{A} 02$ & 11.67 & 6.00 & 0.52 & 33.06 & 44.72 \\
\hline $\mathrm{A} 03$ & 4.00 & 2.00 & 0.52 & 34.00 & 38.00 \\
\hline $\mathrm{A} 04$ & 4.00 & 2.00 & 0.50 & 34.00 & 38.00 \\
\hline $\mathrm{A} 05$ & 2.00 & 1.00 & 0.61 & 34.00 & 36.00 \\
\hline $\mathrm{A} 06$ & 8.00 & 4.00 & 0.52 & 34.00 & 42.00 \\
\hline $\mathrm{A} 07$ & 11.67 & 6.00 & 0.53 & 33.06 & 44.72 \\
\hline $\mathrm{A} 08$ & 4.00 & 2.00 & 0.50 & 34.00 & 38.00 \\
\hline $\mathrm{A} 09$ & 11.67 & 6.00 & 0.53 & 33.06 & 44.72 \\
\hline $\mathrm{A} 10$ & 4.00 & 2.00 & 0.50 & 34.00 & 38.00 \\
\hline $\mathrm{A} 11$ & 4.00 & 2.00 & 0.52 & 34.00 & 38.00 \\
\hline $\mathrm{A} 12$ & 4.00 & 2.00 & 0.50 & 34.00 & 38.00 \\
\hline $\mathrm{A} 13$ & 1.00 & 1.00 & 1.00 & 17.00 & 18.00 \\
\hline $\mathrm{A} 14$ & 1.00 & 1.00 & 1.00 & 17.00 & 18.00 \\
\hline
\end{tabular}

Table 6: Relationship Type and Associated Lag of City Star Al Sahel Project.

\begin{tabular}{|c|c|c|c|c|c|c|c|}
\hline Act.ID & DFd(act) & DF $\Delta$ S(act) & Succ.ID & DFd(succ) & DF $\Delta$ S(succ) & Rel. & Lag \\
\hline A01 & 2.00 & 34.00 & A02 & 11.67 & 33.06 & FF & 11.67 \\
\hline A02 & 11.67 & 33.06 & A03 & 4.00 & 34.00 & SS & 11.67 \\
\hline A03 & 4.00 & 34.00 & A04 & 4.00 & 34.00 & SS & 4.00 \\
\hline A04 & 4.00 & 34.00 & A05 & 2.00 & 34.00 & SS & 4.00 \\
\hline A05 & 2.00 & 34.00 & A06 & 8.00 & 34.00 & SS & 2.00 \\
\hline A06 & 8.00 & 34.00 & A07 & 11.67 & 33.06 & FF & 18.67 \\
\hline A07 & 11.67 & 33.06 & A08 & 4.00 & 34.00 & SS & 11.67 \\
\hline A07 & 11.67 & 33.06 & A09 & 11.67 & 33.06 & SS & 18.67 \\
\hline A08 & 4.00 & 34.00 & A10 & 4.00 & 34.00 & SS & 4.00 \\
\hline A09 & 11.67 & 33.06 & A11 & 4.00 & 34.00 & SS & 18.67 \\
\hline A09 & 11.67 & 33.06 & A12 & 4.00 & 34.00 & SS & 11.67 \\
\hline A10 & 4.00 & 34.00 & A12 & 4.00 & 34.00 & SS & 4.00 \\
\hline A11 & 4.00 & 34.00 & A13 & 1.00 & 17.00 & FF & 1.00 \\
\hline A11 & 4.00 & 34.00 & A14 & 1.00 & 17.00 & FF & 1.00 \\
\hline A12 & 4.00 & 34.00 & A13 & 1.00 & 17.00 & FF & 1.00 \\
\hline A13 & 1.00 & 17.00 & & & & & \\
\hline A14 & 1.00 & 17.00 & & & & & \\
\hline
\end{tabular}


Table 7: Critical Path Method Analysis of City Star Al Sahel Project.

\begin{tabular}{|c|c|c|c|c|c|c|c|c|c|c|}
\hline ID & DFD & Pre.1 & Lag & Pre.2 & Lag & DFES & DFEF & DFLS & DFLF & DFTF \\
\hline A01 & 36.00 & & & & & 0.00 & 36.00 & 0.00 & 36.00 & 0.00 \\
\hline A02 & 44.72 & A01 & $11.67(\mathrm{FF})$ & & & 2.94 & 47.67 & 2.94 & 47.67 & 0.00 \\
\hline A03 & 38.00 & A02 & $11.67(\mathrm{SS})$ & & & 14.61 & 52.61 & 14.61 & 52.61 & 0.00 \\
\hline A04 & 38.00 & A03 & $4.00(\mathrm{SS})$ & & & 18.61 & 56.61 & 18.61 & 56.61 & 0.00 \\
\hline A05 & 36.00 & A04 & $4.00(\mathrm{SS})$ & & & 22.61 & 58.61 & 22.61 & 58.61 & 0.00 \\
\hline A06 & 42.00 & A05 & $2.00(\mathrm{SS})$ & & & 24.61 & 66.61 & 24.61 & 66.61 & 0.00 \\
\hline A07 & 44.72 & A06 & $18.67(\mathrm{FF})$ & & & 40.56 & 85.28 & 40.56 & 85.28 & 0.00 \\
\hline A08 & 38.00 & A07 & $11.67(\mathrm{SS})$ & & & 52.22 & 90.22 & 69.89 & 107.89 & 17.67 \\
\hline A09 & 44.72 & A07 & $18.67(\mathrm{SS})$ & & & 59.22 & 103.94 & 59.22 & 103.94 & 0.00 \\
\hline A10 & 38.00 & A08 & $4.00(\mathrm{SS})$ & & & 56.22 & 94.22 & 73.89 & 111.89 & 17.67 \\
\hline A11 & 38.00 & A09 & $18.67(\mathrm{SS})$ & & & 77.89 & 115.89 & 77.89 & 115.89 & 0.00 \\
\hline A12 & 38.00 & A09 & $11.67(\mathrm{SS})$ & A10 & $4.00(\mathrm{SS})$ & 70.89 & 108.89 & 77.89 & 115.89 & 7.00 \\
\hline A13 & 18.00 & A11 & $1.00(\mathrm{FF})$ & A12 & $1.00(\mathrm{FF})$ & 98.89 & 116.89 & 98.89 & 116.89 & 0.00 \\
\hline A14 & 18.00 & A11 & $1.00(\mathrm{FF})$ & & & 98.89 & 116.89 & 98.89 & 116.89 & 0.00 \\
\hline
\end{tabular}

[19] Elkalla, I.G., Elbeltagi, E., and Elshikh, M.M.Y. (2011). "Project Scheduling with Uncertain Data Using

[9] Arditi, D. and Albulak, M. (1986). "Line-of-Balance in Pavement Construction." Journal of Construction Engineering and Management, Vol. 12, No. 3, PP. 411-424.

[10] Arditi, D. , Tokdemir, O.B. , and Suh, K. (2002). "Challenges in Line-of-Balance Scheduling." Journal of Construction Engineering and Management, Vol. 128, No. 6, PP. 545-556.

[11] Ashley, D.B. (1980). "Simulation of Repetitive-Unit Construction." Journal of the Construction Division, Vol. 106, PP. 185-194.

[12] Bansal, A. (2011). "Trapezoidal Fuzzy Numbers (a, b, c, d): Arithmetic Behavior." International Journal of Physical and Mathematical Sciences, Vol. 2, No. 1, PP. 39-44.

[13] Birrell, G. (1980). "Construction Planning-Beyond the Critical Path." Journal of Construction Engineering and Management, Vol. 106, No. 3,PP. 389-407.

[14] Carr, R.I. and Meyer, W.L. (1974). "Planning Construction of Repetitive Building Units." Journal of Construction Engineering and Management, Vol. 117, No. 4, PP. 579-588.

[15] Chen, S. (2007). "Analysis of Critical Paths in a Project Network with Fuzzy Activity Times." European Journal of Operational Research, Vol. 183, No. 1, PP. 442-459.

[16] Chen, C. and Huang. S. (2007). "Applying Fuzzy Method for Measuring Critical in Project Network." Information Science, Vol. 177, No. 12, PP. 2448-2458.

[17] Chen, S. and Hsueh, Y. (2008). "A Simple Approach to Fuzzy Critical Path Analysis in Project Networks." Applied Mathematical Modeling, Vol. 32, No. 7, PP. 1289-1297.

[18] Chrzanowski, E.N. and Johnston, D.W. (1996). "Application of Linear Scheduling." Journal of Construction Engineering and Management, Vol. 112, No. 4, PP. 476-491.
Fuzzy Logic.” Mansoura Engineering Journal, Vol. 36, No. 3, PP. c1-c12.

[20] Elbeltagi, E., Elkassas, E., Abdel Rasheed, I., and Tawil, S. (2007). "Scheduling and Cost Optimization of Repetitive Projects Using Genetic Algorithms." 17th International Conference Computer Theory and Applications, Alexandria, Egypt.

[21] Elmaghraby, S. (2000). "On Criticality and Sensitivity in Activity Networks.” International Journal of Production Research, Vol. 127, No. 2, PP. 38-220.

[22] El-Rayes, K. (2001). "Objec-oriented Model for Repetitive Construction Scheduling."Journal of Construction Engineering and Management, Vol. 127, No. 3, PP. 199-205.

[23] El-Rayes, K, and Moselhi, O. (1993). "Scheduling of Repetitive Projects with Cost Optimization." Journal of Construction Engineering and Management, Vol. 119 No. 4, PP. 681-697.

[24] El-Rayes, K, and Moselhi, O. (1998). "Resourcedriven Scheduling of Repetitive Projects." Construction Management and Economic, Vol. 16 No. 4, PP. 433-446.

[25] El-Rayes, K. and Moselhi, O. (2001). "Optimizing Resource Utilization for Repetitive Construction Projects." Journal of Construction Engineering and Management, Vol. 127, No. 1, PP. 18-27.

[26] El-Santawy, M.F. and Abd-Allah, S.M. (2001). "The Longest Path Problem in Fuzzy Project Networks: A case Study." International Center for Scientific Research and Studies, Vol. 3, No. 2, PP. 97-107.

[27] Harris, R. B., and Ioannou, P. G. (1998). "Scheduling Projects withRepeating activities." Journal of Construction Engineering and Management, Vol. 124, No. 4, PP. 269-278. 
[28] Hassanein, A. and Moselhi, O. (2004). "Planning and Scheduling Highway Construction." Journal of Construction Engineering and Management, Vol. 130, No. 5, PP. 638-646.

[29] Hassanein, A. and Moselhi, O. (2005). "Acceleration Linear Projects." Construction Management and Economics, Vol. 23, No. 4, PP. 377-385.

[30] Hegazy, T., Elhakeem, A., and Wlbeltagi, E. (2004). "Distributed Scheduling Model for Infrastructure Networks." Journal of Construction Engineering and Management, Vol. 130, No. 2, PP.160-167.

[31] Hyari, K. and El-Rayes, K. (2006). "Optimal Planning and Scheduling for Repetitive Construction Projects" Journal of Management in Engineering, Vol. 22, No. 1, PP. 11-19.

[32] Hegazy, T. and Wassef, N. (2001). "Cost Optimization in Projects with Repetitive Non- Serial Activities." Journal of Construction Engineering and Management, Vol. 127, No. 3, PP. 183-191.

[33] Harmelink, D.J. and Rowings, J.E. (1998). "Linear Scheduling Model: Development of Controlling Activity Path." Journal of Construction Engineering and Management, Vol.124, No. 4, PP.263-267.

[34] Harmelink, D. (2001). "Linear Scheduling Model: Float Characteristics." Journal of Construction Engineering and Management, Vol.127, No. 4, PP.255260.

[35] Jaskowski, P. (2015). "Repetitive Construction Processes Scheduling Using Mixed-Integer Linear Programming", Interdisciplinary Center for Mathematical and Computational Modeling, Vol. 14, No.2, PP. 55-61.

[36] Johnston, D.W. (1981). "Linear Scheduling Methods for Highway Construction." Journal of Construction Division, Vol. 107, No2, PP.247-161.

[37] Kaufmann, A. and Gupta, M.M. (1985). "Introduction to Fuzzy Arithmetic Theory and Applications." Van NostrandReinhold Publishing Co., New York, N.Y.

[38] Liu, S.S. and Wang, C.J. (2007). "Optimization Model for Resource Assignment Problems of Linear Construction Projects." Automation in Construction, Vol. 16, No. 4, PP. 460-473.

[39] Liu, Y., Yang, S.M. and Lin, Y. (2010). "Fuzzy Finish Time Modeling for Project Scheduling." Journal of Zhejiang University Science, Vol. 11, No.12, PP. 946-952.

[40] Lorterapong, P. and Moselhi, O. (1996). "Project Network Analysis Using Fuzzy Sets Theory" Journal of Construction Engineering and Management, ASCE, Vol.122, No. 4, PP.308-318.

[41] Lumsden, P. (1968). "The Line of Balance Method." Pergamon, Telgamon press Ltd, London, England.

[42] Mahdi, I.M. (2004). "A New Approach for Planning Repetitive Housing Projects." International Journal of Project Management, Vol. 22, No. 4, PP. 339-346.

[43] Mattila, K.G. and Park, A. (2003). "Comparison of Linear Scheduling Model (LSM) and Critical Path Method (CPM)." Journal of Construction Engineering and Management, Vol. 129, No. 1, PP. 56-64.
[44] Malcolm, D.G., Roseboom, J.H., Clark, C.E., and Fazar, W. (1959). "Application of A technique for Research and Development Project Evaluation." Operational Research, Vol.7,No.6, PP. 46-69.

[45] Maravas, A. and Pantouvakis, J. (2011). "A Process for the Estimation of the Duration of Activities in Fuzzy Project Scheduling." Vulnerability, Uncertainty, and Risk, ASCE: PP. 62-69

[46] Moselhi, O. and Hassanein, A. (2003). " Optimized Scheduling of Linear Projects." Journal of Construction Engineering and Management, Vol. 129, No. 1, PP. 56-64.

[47] Naaz, S., Alam, A. and Biswas, R. (2011). "Effect of Different Defuzzification Methods in a Fuzzy Based Load Balancing Application." International Journal of Computer Science Issue, Vol. 8, No. 5, PP. 261-267.

[48] Nassar, K. (2005). "Evaluation Optimization of Resource allocation in Repetitive Construction Schedules." Journal of Information Technology in Construction, Vol. 10, PP. 265-273.

[49] Raoufi,M. and Fayek, A. (2018b). "Fuzzy agentbased modeling of construction crew motivation and performance." Journal of Construction Engineering and Management, Vol. 32, No. 5, PP. 04018035(1-16).

[50] .Raoufi,M. and Fayek, A. (2020). "Fuzzy Monte Carlo Agent-Based Simulation of Construction Crew Performance." Journal of Construction Engineering and Management, Vol. 146, No. 5, PP. 04020041 (113).

[51] Reda, R. (1990). "RPM: Repetitive Project Modeling." Journal of Construction Engineering and Management, Vol. 114, No. 1, PP. 39-52.

[52] Ross, J. T. (2005). "Fuzzy Logic with Engineering Application." Wiley India Publishing Co., Ansari Road, Daryaganj, New Delhi.

[53] Russell, A., Caselton, W. (1998). " Extensions to Linear Scheduling Optimization." Journal of Construction Engineering and Management, Vol. 114, No. 1, PP. 36-52.

[54] Selinger, S. (1980). "Construction Planning for Linear Projects." Journal of Construction Division, Vol. 106, No. 2, PP. 195-205.

[55] Senouci, A.B. and El-Din, N.N. (1996). "Dynamic Programming Approach to Scheduling of Non-Serial Linear Project." Journal of Computing in Civil Engineering, Vol. 10, No. 2, PP. 106-114.

[56] Senouci, A. and Naji, K. (2006). "A Computerized System for Scheduling and Cost Optimization of NonSerial Linear Projects." Surveying and Built Environment, Vol. 17, No. 2, PP. 49- 62.

[57] Shaked, O. and Warszawskiz, A. (1995). "Knowledge Based System for Construction Planning of High Rise Buildings." Journal of Construction Engineering and Management, Vol. 121, No. 2, PP. 172-182.

[58] Sireesha, V. and Shankar, N.R. (2010). "A New Approach to Find Total Float Time and Critical Path in A Fuzzy Project Network." International Journal of Engineering Science and Technology, Vol. 2, No. 4, PP. 600-609. 
[59] Soltani, A. and R. Haji (2007). " A Project Scheduling Method Based on Fuzzy Theory" Journal of Industrial and Systems Engineering, Vol. 1, No. 1, PP. 70-80.

[60] Stradal, O. and Cacha, J. (1982). "Time Space Scheduling Method." Journal of the Construction Division, Vol. 108, No. 3, PP. 445-457.

[61] Suhaih, S. and Neale, R. (1994). "CPM/LOB: New methodology to integrate CPM and Line of Balance." Journal of Construction Engineering and Management, Vol. 120, No. 3, PP. 667-684.

[62] Tokdemir, O.B., Arditi, D.A., and Balcik, C. (2006). "ALISS: Advanced Linear Scheduling System." Construction Management and Economics, Vol. 24, No. 12, PP. 1253-1267.

[63] Van-Slyke, R.M. (1963). "Monte-Carlo Method and the PERT Problem." Operational Research, Vol. 11, No. 5, PP. 60-839.

[64] Vorster, M. C., and Bafna, T. (1992). "Formal Development of Line of Balance Technique." Journal of Construction Engineering and Management, ASCE, Vol. 118, No. 1, PP. 210-211

[65] Yamin, R.A. and Harmelink, D.J. (2001). "Comparison of Linear Scheduling Model (LSM) and Critical Path Method (CPM). " Journal of Construction Engineering and Management, Vol. 127, No. 5, PP. 374-381.

[66] Yang, I.T. and Ioannou, P.G. (2001). "ResourceDriven Scheduling for Repetetive Projects: A PullSystem Approach." Proceedings of 9th International Group for Lean Construction Conference, Singapore, PP. 365-377.

[67] Zadeh, L.A. (1965). "Fuzzy Sets." Information and Control." Information Science, Vol. 8, No. 3, PP. 338353.

[68] Zadeh, L.A. (1978). " Fuzzy Sets As A Basis for A Theory of Possibility." Fuzzy Sets and Systems, Vol. 1, No. 1, PP. 3-28.

[69] Zammori, F.A., Braglia, M. and Frosolini, M. (2009). " A Fuzzy Multi-Criteria Approach for Critical Path Definition." International Journal of Project Management, Vol. 27, No. 3, PP. 278-291. 